International Journal of Engineering \& Technology, $7(2.29)(2018) 210-214$
International Journal of Engineering \& Technology
Website: $w$ ww.sciencepubco.com/index.php/IJET
Research paper

\title{
Sustainability of a beach resort: A case study
}

\author{
Mazlina Mustapha ${ }^{1 *}$, Khairil Wahidin Awang ${ }^{2}$ \\ ${ }^{1}$ Faculty of Economics and Management, Universiti Putra Malaysia \\ ${ }^{2}$ Faculty of Hospitality, Tourism and Wellness, Universiti Malaysia Kelantan \\ *Corresponding author E-mail: mazlina05@gmail.com
}

\begin{abstract}
In Malaysian Eleventh Plan 2016-2020, tourism is one of the service sectors given priority by the government. It is claimed that the increase in tourist arrivals help to support the deficit reduction in service sector by contributing to the growth of the nation. Furthermore, the quick growth of tourism in Southeast Asia, as a result of amongst others attractive sandy beaches and nature, beach resorts have been on the receiving end of attention and focus by the tourists. However, prior studies claimed that these resorts were not properly managed and further actions need to be taken to ensure its sustainability. Thus, this case study aims to examine performance management of a beach resort in ensuring its sustainability. Specifically, this study explores the cost saving strategies adopted by this resort through its 25 years of operation. This resort is located on an island in Terengganu. The resort owner and employees were interviewed. The interview results appear to indicate that various strategies were implemented by the resort to manage their performance and ensure its sustainability in the business. Family members hold important positions in the resort to ensure the smooth running of the operation. Cost saving activities and smart business arrangements were made with suppliers to reduce its outflows.
\end{abstract}

Keywords: Beach resort; Performance management; Sustainability; Tourism industry.

\section{Introduction}

The tourism industry has continued to be a significant contributor to Malaysia's economic growth (1). The industry recently achieved to become a major foreign exchange earner second to be exact after manufacturing in 2013. It is Malaysia's sixth biggest sector in 2013, edging one spot up from the year 2012 contributing RM51.5 billion to Gross National Income (GNI) (2). The government also gives priority to tourism in the Malaysian Eleventh Plan 2016-2020 (3). Statistics for 2014 also show that tourism as an industry contributed RM72 billion, a $27.4 \%$ increase from the year 2010 at RM56.5 billion. This significant contribution further resulted in tourism being listed as one of the National Key Economic Areas (NKEAs). As one of the NKEAs, it is forecasted to contribute about RM168 billion by the year 2020 with 36 million tourist arrivals $(4,5)$. Contributions come in many forms and one of them is via the tourism industry's accommodation sector.

Beach resort is a popular accommodation type offered to both, Malaysian and foreign tourist alike. Smith (6) notes that beach resorts evolve naturally through the expansion of accommodation sector plus other recreational functions. Malaysia has attractive beaches that offer beautiful scenery and crystal clear water. Wong (7) supported this notion whereby he claimed that basic natural resources which Malaysia is rich for like islands, sandy beaches and coral reefs necessitates and helps in the development of beach resorts. In parallel, Smith (8) posited that demand for beach holidays was high, particularly within Asia Pacific.

Similarly it is reported that Malaysia's beach resorts has increased steadily in numbers, especially those located on islands. The increasing number of resorts creates stiff competition among themselves. They would need to continuously be relevant in today's market, providing space to stay as well as attracting the tourists and locals. In addition, these island or beach resorts also need to find ways to survive as their operating days are shorten by natural element. The monsoon season which lashes the islands resulted in resorts operating less than all year round. It is reported that monsoon season faced by beach resorts forced the management to temporarily close their businesses during certain months of the year (9). It is also claimed that the number of tourists who patronized the islands during the monsoon, which happens every year from November until March the following year reduce to a paltry number. It is reported that the east coast islands of Malaysia are closed during this season due to heavy rain and rolling seas. Thus, it is very crucial for the resorts to manage their performance and sustain in the business. Harris and Mongiello (10) stated that with increase in competition, and unfavorable seasonal climate surrounding the resorts, the resorts must ensure effective operations and business decision-making tasks are in place.

Smith (6) posits too that beach resort development especially in Asia Pacific usually starts off well but ends with detrimental features and impacts. He stated that beach resorts in the region had underwent deterioration of quality as time flew by particularly when the scale of physical development increased myriad with increased congestion and pollution. Hence, beach-related recreational quality deteriorate. Agarwal (11) claimed that beach resorts will have to continuously re-orientate and rejuvenate their products and facilities in order to keep up with similar type destinations which keep on attracting tourists.

Moreover, it is also claimed that with the rapid growth of tropical beach resorts (6), it is claimed that all tourism stakeholders should play a role in helping sustainability to be achieved (12). Prior studies posited that the ideal situation for achieving what is desired would be to get everyone to move in the same direction and it can be done through the management of the organization via perfor- 
mance management (13). However, there are limited studies in the area of beach resorts as highlighted by Stewart (14). Thus, this case study aims to explore how the management of an island resort in the east coast of Malaysia (Resort A) manage its performance. The study explores the strategies used by this beach resort which manages to sustain business for the last 25 years.

\section{Review of Literature}

\subsection{Hotel and the tourism industry in Malaysia}

It is no secret that development activities undertaken in the Malaysia's tourism industry was due to several major global economic recessions that took place in the early 1970 s and 1980s resulting in the government plan on widening the country's economic base (15). The decreased in commodity prices in the 1970 s whereby Malaysia depended so much on the export of rubber and tin, and subsequently the global financial crisis in mid 1980s which resulted in world recession, made the government look up to tourism as the savior. Tourism industry in Malaysia is deemed to have been successful as it managed to attract foreign tourists and at the same time managed to tackle and evade problems that hit many tourist destinations in other countries (16). Ap, Var (17) mentioned that in 1985 Malaysia had become popular and increasingly known as a popular Islamic tourist destination among foreign visitors. The government too emphasized domestic tourism in order to further spur the industry. These moves had successfully triggered the rapid development of tourism industry in Malaysia (18).

Tourism industry comprises various subsectors such as transportation, shopping, travel and tour services, restaurants, and accommodation (19). Another study claimed that many other related industrial sectors benefitted from the tourism industry (20). Among the subsectors, hotels or the accommodation sector plays a significant part in the growth of tourism in Malaysia with a contribution of $30.4 \%$ of total tourist expenditure in 2014. It is claimed that the accommodation is the highest contributor among all tourism-related subsectors for the past five years. Therefore, the accommodation is regarded as a key subsector of the tourism industry (21), and is entrusted with a significant role to play so that it can continuously contribute to tourism development (22). Mazumder, Ahmed (23) suggest that the hotel subsector also promotes and provides employment opportunities to Malaysians. In addition, the subsector also contributes to Malaysia's economy in terms of added and alternative incomes for the rural population, giving support to the growth of secondary activities like equipment plus material suppliers, and on top of that, giving a boost to both domestic and inbound tourism expansion $(24,25)$.

In the year 1990, Visit Malaysia programs were launched and the number of tourist arrivals particularly from neighboring countries tremendously increased and this urged the government to plan for the country's future economic growth through promotion (26) Malaysia's popularity as a destination for tourists can be seen from the increasing number of tourist arrivals as presented in Table 1 below:

Table 1: Tourist Arrivals and Receipts to Malaysia 2004-2016

\begin{tabular}{|l|l|l|}
\hline Year & Arrivals & Receipts (RM) \\
\hline $\mathbf{2 0 0 4}$ & 15.70 million & 29.7 billion \\
\hline $\mathbf{2 0 0 5}$ & 16.43 million & 32.0 billion \\
\hline $\mathbf{2 0 0 6}$ & 17.55 million & 36.3 billion \\
\hline $\mathbf{2 0 0 7}$ & 20.97 million & 46.1 billion \\
\hline $\mathbf{2 0 0 8}$ & 22.05 million & 49.6 billion \\
\hline $\mathbf{2 0 0 9}$ & 23.65 million & 53.4 billion \\
\hline $\mathbf{2 0 1 0}$ & 24.58 million & 56.5 billion \\
\hline $\mathbf{2 0 1 1}$ & 24.71 million & 58.3 billion \\
\hline $\mathbf{2 0 1 2}$ & 25.03 million & 60.6 billion \\
\hline $\mathbf{2 0 1 3}$ & 25.72 million & 65.4 billion \\
\hline $\mathbf{2 0 1 4}$ & 27.44 million & 72.0 billion \\
\hline $\mathbf{2 0 1 5}$ & 25.70 million & 69.1 billion \\
\hline $\mathbf{2 0 1 6}$ & 26.76 million & 82.1 billion \\
\hline
\end{tabular}

Source: Malaysia (27)
Tourist arrivals in Malaysia started to increase gradually beginning year 2004 due to many programs and promotion undertaken by the government. Among the programs conducted by the government and participated by many other tourism stakeholders were the Visit Malaysia Year Campaign, Malaysia My Second Home Program, Homestay Program, Agro Tourism and Sport Tourism. Prior studies claimed that the increase in tourist arrivals in Malaysia over the years is paralleled with increase in the supply of hotel and room number (28). Total receipts from tourists increase from RM29.7 billion in 2004 to 82.1 billion in the year 2016. A slight decrease of tourist arrivals and receipts in 2015 is most probably

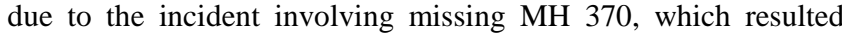
among others in the cancellation of many flight trips from mainland China to Malaysia. The hotel sector as part of the tourism industry is aimed to help the government in realizing the economic benefits that would ultimately lead to the country's growth (22).

\subsection{Beach Resorts}

Medlik and Ingram (29) defined hotels as a business that caters to services such as accommodation, food and drinks for guests or temporary residents who wish to stay at the hotel. Since hotels are in the service sector, they should emphasize on improving the service quality to stay relevant and competitive in the business industry (30). It is claimed that customer's loyalty and satisfaction is enable to be retained and increased by firms concentrating on delivering best service that they are able to give to the customers (31).

Smith (8) stated that with rapid increase of tourism in Southeast Asia, incoming individual hotel and beach resort projects were given careful attention in their planning and design stages. Integrated resorts were given attention as early as in the 1970 s. Investigations on beach resorts were mainly on North American and British soil and only minor studies were carried out focusing on Mediterranean and Middle East regions whereby the latter had prospered even better than the British resorts (32). Chan (33) found that limited number of research or studies had been done regarding beach resorts in Malaysia even when the arrival of tourists had been growing steadily and the tourism industry showing its importance in the country's economic growth.

The coastline has been an attraction for tourists and it is vital for a country to manage its beaches in a sustainable way (34). Attractive sandy beaches plus other natural elements associated with the coastline resulting in worldwide development of beach resorts (35) Beach resort is defined as individual or more than one tourist lodgings that are location wise beach-fronted irrespective of the accommodation's quality (7).

According to Mahathir (36), development of beach resorts may lead to a country generating a larger foreign exchange earnings and this can be possible through the tourism industry's growth. This can also be led by the desire to improve the conditions or well-beings of its citizens through increase employment opportunities and better income generation. In the early growth of tourism industry, beach resorts were given the most attention since tourists who aimed to have relaxing holidays were attracted to the islands in Malaysia.

In order to sustain their businesses, beach resorts have to continuously re-orientate and rejuvenate their products and facilities so as to compete with their competitors and attract more tourists (11). According to Pine and Philips (37), it is important to have high quality management for a developing hotel sector, in order to offer best quality services that would lead to customer satisfaction. Thus, proper strategies and management of the performance must be maintained by these resorts.

\subsection{Performance Management}

Performance is an important element when assessing a success of an organization and it reflects the factors used by managers in assessing the functions of an organization (38). Performance levels achieved create information for managers, spurring operation's 
modification and adjustments. Lebas (39) defined performance in relation to the future, the ability of a corporation to fulfill what is targeted while fulfilling the needs of its customer. It is claimed to be case specific and decision-maker specific, and to be measuring performance in a retrospective view would not be adequate. Sahoo and Jena (40) asserted that several factors would affect performance management of an organization and the implementation of this system must be considered carefully. Organizations will have to take into account their strengths, weaknesses, opportunities and threats in order to operate in a competitive environment while critically scanning the environment to take advantage of the situation should any economic, social or technological changes occur. Each company is be saddled with a multitude of external and internal forces which, on one side compromises potential limitations with respect to the company's objectives or performance it desires to achieve (41). On the other hand, it also compromises potential stimulants. Managers will have to filter through all the information they received, and choose and focus on only relevant information in terms of timeliness. A company's good performance is a result of good management of information and strategies taken by the company.

\section{Research Methods}

The research project utilizes a case study of a resort on an island off shore Peninsular Malaysia's eastern coast (Resort A) to analyse the implementation of performance management and how it assists to sustain the business. The research examines the strategies implemented by the resort. This resort is chosen because of its excellent performance and manages to sustain in business since the last 25 years. It is also located on an island which is affected by the northeast monsoon which brings in heavy rains, strong winds and rolling sea which force the management to close business for about three months each year.

This study employs a qualitative approach as oppose to a quantitative one. The owner cum manager and the employees of the resort were interviewed. Prior to the interviews, the resort was contacted to obtain their agreement to participate in the research exercise. Before starting each interview, the researchers informed the interviewees on the aims of the research project and its related objectives. Permission to tape-record the interviews was put forward before the interviews begun. The interviewees were also assured of the confidentiality of the information they gave.

A semi-structured questionnaire was utilized as the researchers' guideline for the interviews. Questions asked revolve on how the owner / manager manage the operation of the resort for the last 25 years. The interviews, which were conducted in August 2016 at the resort site, ranged in duration from a maximum of two hours to a minimum of an hour. The interviews were digitally recorded and the contents were subsequently transcribed and analyzed. Axial coding was used to segmentized the transcriptions into informed thematic data.

\section{Results and Discussion}

\subsection{Background of Resort A}

Resort A is located on an island in east coast of Malaysia. It is owned by Encik AA. Initially, in early 1990s, Encik AA started as a boatman who ferried tourists from/to the mainland. In 1992, tired of driving the boat, he decided to start his own shop on a land he inherited from his father. He constructed a small rudimentary shop that sold simple provisions such as biscuits, sweets and mineral water. At that time, there was no electricity on the island. He used oil lamp at his shop at night. During that time, the number of tourists going to the island was still small. However, as the shop was the only one on that side of a long beach, it became popular among the tourists.

Later, Encik AA started to build 10 units of chalets on the same piece of land, which was fully completed in 1994 . He noticed that tourists staying at his chalets had difficulties in getting their meals; this prompted him to open a restaurant in 1998. The restaurant managed to attract more tourists as well as locals from other resorts and the business was very good for Encik AA.

As time went by, the island became very popular among tourists and statistics of arrivals increased tremendously. In 1999, Encik AA decided to build more chalet units. By the end of that year another 14 chalets and 2 dormitories were completed and ready to be rented. In 2016, Encik AA renovated and expanded the sizes of his restaurant and shop so that he can provide better services to his customers.

This business started very small and with very basic amenities. After 25 years in operations, it manages to expand and sustain in business. Currently this resort has a comfortable restaurant, a new grocery shop, four boats and 24-rooms chalets plus 2-dormitories. Thus, this study aims to explore the strategies that the resorts adapted through the years to reach this level. The researchers interviewed the owner, Encik AA and other resort employees so as to comprehend related issues of interest.

\subsection{Strategies adapted by Resort A}

The owner Encik AA, was asked about the strategies he adopted since the start of his business in 1992. He shared that the resort's operation was mainly handled by his family members. His wife takes care of the accounts related matters, and his daughter takes charge of the chalets. His first son, who stationed in Kuala Lumpur, promotes the resort and in-charge of finding potential customers for the resort. He would also oversee the expansion and development processes of the resort as he has engineering background. The family members take charge of the core functions of the resort. According to Encik AA, this ensures that each function is done efficiently. If there is any problem, they will sit down and discuss and try to solve the problem. This strategy helps to ensure smooth running of the resort. Encik AA commented that:

"....my son did the planning, he is an engineer...building consultant...he planned this shop, he planned it...he also monitored the construction activities"

"...my daughter is in-charge of the chalet....she has been doing that for some time..."

"aaa... I don't know much about accounts ......my wife handles the numbers... ... ...my job is to operate the business...to manage the staff and to manage the materials...my wife holds the money..."

Other employees of the resort are locals (people from the island) and among his close family members too. This is a different approach compared to other resorts on the island which employ foreign workers and people from the mainland. According to Encik AA, by employing locals, the resort will not have unexpected shortage of employees, as they are familiar with the situation on the island. It is claimed that working environment on an island is different compared to working on the mainland. Working on an island would require the employees to devote to their work, live in isolation and away from entertainment or other community. Sometimes when the employees expressed their intention to resign, the resort just had to let them go and did not want to force them to stay, as this might affect their work at the resorts. Consequently, this may cause occasional shortage of employees at the resorts.

The employees also are provided with meals and accommodation at the back of the resort.

"...they live upstairs...there are rooms for them...for the staff...there are 12 rooms..."

"this 2 storey building, special for the staffs here...we provide food...they just come here and work only we are one big family."

They are required to go through on the job training to improve their skills. They are treated as part of a big family by the owner. This approach also provides a win-win condition for that resort and surrounding community. The resort provides the employment opportunities for the islanders, cascading economic benefits to the local community. For example, Encik AA appoints a company 
owned by his close family member to do maintenance work for his chalets. His strong family relationship and his close relationship with the islanders help him to run his business smoothly. He believes that this is his way of contributing to the people on the island.

In addition, the resort also conducted a few cost saving activities in order to save cost and curb cash outflow. The fixed assets and the development / expansion of the resort are normally bought and done on cash term without assistance from bank or financial institution. This means the resort does not have to pay any interest related to financing and do not have any monthly obligation to meet at month end. Encik AA commented that:

"I have the experience... we slowly grow from below..."

".....we think about our business, ......the cost or charge involved ...if we can avoid that, we try to."

"it is easier to build by using our own money...no commitment, there is no monthly installment to pay to the bank."

The promotion and marketing of the resort is done on their own without hiring any booking agent which may involve some cost All the promotion is done by Encik AA's son in Kuala Lumpur. Booking and reservation of rooms would be communicated to his sister who is in-charge of the chalet so as to organize and handle the matter smoothly. According to the owner, his chalet units are almost always fully booked during weekends and working days due to information spread out by their previous customers/ tourists - words of mouth works very well for this resort. They always strive to give the best to their customers. About $60 \%$ of his customers are locals and the balance are foreign tourists. Most of foreigners come from Germany, Italy and Australia. Encik AA claimed that:

"we do not use booking agent...our customers will normally call me or my son ...or through email and blogs set up by my daughter who takes care of the chalet"

".....we are always full...every week...normal days just foreign tourists... ...Thursday, Friday, Saturday, Sunday, we have locals ...... we are full until not enough rooms..."

The resort also plans their expansion activities smartly. All development and expansion activities of the resort were done during the monsoon season when the resort was closed from customers. During this time no activity was going on at the resort and no customers were around too. Thus, the expansion activities would not disturb the customers with noise and dust from construction at the resort or the restaurant. By planning the construction to be executed during the monsoon season, the resort will not lose any income as it is not within its operating period.

The resort needs to buy wet and dry groceries everyday as it has a restaurant to operate. Wet groceries include chicken, meat, fish and vegetables which would need to be ordered daily for the daily operation of the restaurant. Over the years Encik AA has developed close relationship with the groceries' suppliers on the mainland. He has made a win-win business arrangement with his long time suppliers on the mainland to deliver these groceries daily to him at the resort. He will pay them cash on delivery and they will deliver the groceries directly to his resort. This will save time and transportation cost for the resort and confirm market for the suppliers. Encik AA claimed that:

"we place our orders with our long time suppliers at Kuala Besut [on the mainland] ...they send to our resort using cargo boat... we order every day ... we just go over there once a week for dry materials..."

"we call at 7 am in the morning, we place our order, meat, fishes, vegetables...they will send to us...they send using cargo boat...usually they deliver by noon 12 pm everyday..."

Electricity is not available on the island except at the main and only village of the island. All the resorts on the island have to make their own arrangement relating to electricity. Resort A uses three diesel generators to provide electricity and it provides 24 hours electricity to its customers. Each generator operates in shifts-timing every day. Each generator will operate for 8 hours daily. In order to save cost, Encik AA always buy the diesel to run the generators by bulk as this is cheaper. He expressed his frustra- tion about this as the cost of buying and maintaining the generators are very expensive. Another problem that he has to encounter at the island is no proper drainage system for the resorts on the island. He really hopes more initiatives are carried out by the federal government and local council.

"I heard that TNB has plan for electricity at the island......but I do not know.....it took 3 or 4 years for them to check...this island still does not have electricity except for the village.... I really hope they can expedite this to support resorts on this island."

"...the maintenance costs of the generators are very high....the diesel price is always fluctuating..... We have to prepare for the diesel and we must have spare diesel..... if we do not have it.... we cannot operate our chalets, restaurant and shop....it will be dark at night and can be very hot too.... air-cond cannot work..... "'

"....there is no drain..... small drain only, ... the authority have a plan to build sewerage treatment plant.... but to date there is no sight of it till now...."

These interview findings indicate that local council and federal government must re-look at those projects which were planned years ago, but still did not materialized. As a result the islanders do not get the benefit of the facilities as other citizens on the mainland.

\section{Conclusion}

This case study shows that the resort uses various strategies to manage their performance and ensure its sustainability in the business. It hires family members to hold important positions in the resort to ensure the smooth running of the operation. It practices high trust and family-like relationship between the employers and employees. Cost saving activities and win-win business arrangements were made with suppliers to reduce its outflows.

In addition, the resort also helps to generate the economy of the island, and provides employment opportunities to islanders. However, the results also indicate that the resort also needs help. Improvements need to be done in some areas, especially relating to electricity and drainage system. All parties (such as the NGOs, federal government, local communities, and private sectors) must put more effort and work towards contributing to development of the island. Tourism success shall not be only evaluated with respect to the number of increased foreign tourist arrivals as well as gross tourism revenues. Instead it shall also be measured according to how the industry is integrated with the national and local economy, plus to how tourism contributes to the total development of local community and the island itself.

\section{Acknowledgement}

This research work is supported by the FRGS grant (5524888).

\section{References}

[1] Bhuiyan AH, Siwar C, Ismail SM. Tourism Development in Malaysia from the Perspective of Development Plans. Asian Social Science. 2013;9(9):11-8

[2] Culture MoTa. Speech by Minister of Tourism and Culture Malaysia - Signing of Memorandum of understanding between Ministry of Tourism and Culture ,2014 12 May 2017. Available from: http://www.motac.gov.my/en/archives/2015/742-speech-byyb-dato-seri-mohamed-nazri-bin-tan-sri-abdul-aziz,-minister-oftourism-culture,-malaysia-signing-of-memorandum-ofunderstanding-between-ministry-of-tourism-and-culture,-malaysiaand-visa.

[3] (GOM) GoM. Eleventh Malaysia Plan 2006-2020 Kuala Lumpur: Percetakan Nasional Malaysia Berhad; 2015.

[4] Kaur I. Performance measurement: An evaluation of cooperative performance in Malaysia. Malaysian Journal of Co-Operative Management. 2006;2:14-28.

[5] Malaysia expected to reap RM168 billion from tourism by 2020 Astro Awani Online. 20139 October, 2013.

[6] Smith RA. Beach resorts: A model of development evolution. Landscape and Urban Planning. 1991;21:189-210. 
[7] Wong PP. Coastal tourism development in Southeast Asia: relevance and lessons for coastal zone management. Ocean \& Coastal Management. 1998;38:89-109.

[8] Smith RA. Review of integrated beach resort development in Southeast Asia. Land Use Policy. 1992;9(3):209-18.

[9] Resort Chalets in Terengganu halts operations following monsoon season. The Star Online [Internet]. 201616 April 2017. Available from: http://www.thestar.com.my/news/nation/2016/10/04/resortschalets-in-terengganu-halt-operation-following-monsoon-season/.

[10] Harris PJ, Mongiello M. Key performance indicators in European hotel properties: General managers' choices and company profiles. International Journal of Contemporary Hospitality Management. 2001;13(3):120-8.

[11] Agarwal S. The resort cycle and seaside tourism: an assessment of its applicability and validity. Tourism Management. 1997;18(2):65 73.

[12] Salehudin MS, Prasad DK, Osmond PW, editors. Challenges to sustainable resort and hotel development in Malaysia. International Conference on Tourism , Transport and Logistics 2013,; 2013; Bangkok, Thailand: UP Organiser and Publication Co. Ltd.

[13] Dransfield R. Human Resources Management London: Heinemann; 2000.

[14] Stewart CJ. Recretional and development carrying capacities of coastal environments. A review of relevant literature and research. Mississauga, Ontario: Christrian J Stewart Consulting, 1993.

[15] Mohd Salleh NH, Othman R, Ramachandran S. Malaysia's tourism demand from selected countries: The ARDL approach to cointegration. International Journal of Economics and Management. 2007;3(3):345-63.

[16] Din KH. Tourism in Malaysia competing needs in a plural society. Annals of Tourism Research. 1982;9:435-80.

[17] Ap J, Var T, Din K. Malaysian perceptions of tourism. Annals of Tourism Research. 2002;18(2):321-3.

[18] Awang KW, Aziz YA, Samdin Z. Pattern of Small Hotel Busineessess: A Perspective from the Practitioners. Journal of Tourism, Hospitality \& Culinary Arts,. 2011;3(3):69-84.

[19] Foo LY, Othman M. Data envelopment analysis to measure eficiency of hotels in Malaysia. SEGi Review. 2011;4(1):25-36.

[20] Kusni A, Kadir N, Nayan S, editors. Determinants of Tourism Demand in Malaysia by Tourists from ASEAN Countries: A Panel Data Econometric Analysis. International Academic Conference 2013; 2013; Dungun.

[21] Auzair MS. The effect of business strategy and external environment on management control systems: A study of Malaysian hotels. International Journal of Business and Social Science. 2011;2(13):236-44.

[22] Abu Kasim NA, Minai B. Linking CRM strategy, customer perfoemance measures and performance in the hotel industry. International Journal of Economics and Management. 2009;3(2):297-316.

[23] Mazumder MNH, Ahmed EM, Al-Amin AQ. Does tourism contribute significantly to the Malaysian economy? Multiplier analysis using I-O technique. International Journal of Business and Management. 2009;4(7):146-59.

[24] Abd Patah MOR, Mohd Radzi S, Abdullah R, Adzmy A, Zain RA Derani N. The influence of psychological empowerment on overall job satisfaction of front office receptionists. International Journal of Business and Management. 2009;4(11):167-76.

[25] Awang KW, Ishak N, Mohd Radzi S, Taha A. Environmental variables and performance: Evidence from the hotel industry in Malaysia. International Journal of Economics and Management. 2008;2(1):59-79.

[26] Picard M, Wood RE. Tourism, Ethnicity, and the State in Asian and Pacific Societies. Honolulu: University of Hawaii Press 1997.

[27] Malaysia T. Tourists arrival and receipts to Malaysia by year2017 13 May 2017. Available from: http://www.tourism.gov.my/statistics

[28] Cheng BL, Abdul Rashid Z. Service Quality and the Mediating Effect of Corporate Image on the Relationship between Customer Satisfaction and Customer Loyalty in the Malaysian Hotel Industry, Gadjah Mada International Journal of Business. 2013;15:99-112.

[29] Medlik S, Ingram H. The Business of Hotels Boston, Massachusetts: Butterworth: Heinemann; 2000.

[30] Hueic CT, Easvaralingam Y. Perceptions of Service Quality, Corporate Image, and Customer Loyality in the Hotel Industry of Malaysia,. 2nd International Research Symposium in Service Management; Yogyakarta, Indonesia2011.

[31] Seth N, Deshmukh SG, Vrat P. Service quality models: a review. International Journal of Quality \& Reliability Management. 2005;22(9):913-49.

[32] Shoval N, Cohen-Hattab K. The role of the state and the rise of the Red Sea resorts in Egypt and Israel. In: Agarwal S, \& Shaw, G., editor. Managing coastal tourism reports: a global perspective. Clevedon: Channel View Publication; 2007. p. 235-49.

[33] Chan J. Understanding Coastal Seaside Resorts in Sabah: Its Growth Factors, Key Attributes and Operational Strategies. Tourism , Leisure and Global Change. 2014;1(6):12-23.

[34] Jennings S. Coastal tourism and shoreline management. Annals of Tourism Research. 2004;31(4):899-922.

[35] Wong PP. The geomorphological basis of beach resort sites- Some Malaysia examples. Ocean \& Shoreline Management. 1989;13:12747

[36] Mahathir M. The official opening of the 50th Pacific Asia Travel Association. 50th Pacific Asia Travel Association (PATA); 9 April 2001; Kuala Lumpur2001.

[37] Pine R, Philips P. Performance comparisons of hotels in China. International Journal of Hospitality Management. 2005;24(1):57-73

[38] Van De Ven AH, Delbecq A, Koenig R. Determinants of coordination Modes within organizations. American Sociology Review. 1976;41(2):322-38.

[39] Lebas MJ. Performance Measurement and Performance Management. International Journal Production Economics. 1995;41:23-35.

[40] Sahoo CK, Jena S. Organizational performance management system: exploring the manufacturing sectors. Industrial and Commercial Training. 2012;44(5):296-302.

[41] Houben G, Lenie K, Vanhoof K. A knowledge-based SWOT analysis system as an instrument for strategic planning in small and medium sized enterprises. Decision Support Systems. 1999;26:12535 . 